\title{
Primary Cutaneous Large B-Cell Lymphoma, Leg Type, Localized on the Dorsum
}

\author{
A. Patrizi ${ }^{a}$ \\ B. Raone ${ }^{a}$ \\ E. Sabattini ${ }^{\mathrm{b}}$ \\ C. Guriolia \\ A. Pileri Jr. ${ }^{a}$ \\ C. D'Acunto ${ }^{a}$ \\ aDermatology, Department of Internal Medicine, Geriatrics and Nephrologic

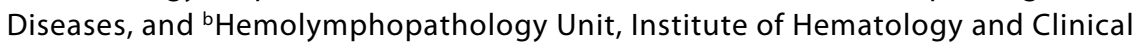 \\ Oncology 'L.A. Seragnoli', University of Bologna, Bologna, Italy
}

\section{Key Words}

B lymphocytes · Histopathology · Immunohistochemistry - Lymphoma · Nodules · Skin . Primary cutaneous large B-cell lymphoma, leg type

\begin{abstract}
Primary cutaneous large B-cell lymphoma, leg-type (PCLBCL-LT), is a large B-cell lymphoma primarily involving the skin. It is distinguished from the other 3 subsets of this lymphoproliferative disorder by its immunohistopathological features, configuring confluent sheets of medium-sized to large $B$ lymphocytes with round nuclei provided with evident nucleoli, resembling centroblasts or immunoblasts, which express Bcl-6, $\mathrm{Bcl}-2$. Prevalently appearing on the lower limbs, as a single or multicentric and frequently ulcerated skin nodule or plaque, PCLBCL-LT has a worse prognosis than the other large B-cell lymphomas. Moreover, the age of onset is delayed (7th decade) compared to those of the other 3 subtypes (6th decade); it presents a slight female predominance (2:1), and a higher percentage of positivity to $\mathrm{Bcl}-2$. We present a 52 -year-old man who showed a 2-year standing, non-ulcerated, round, $4 \mathrm{~cm}$ in diameter, red plaque, medially located on the dorsum. After biopsy the diagnosis of PCLBCL-LT was made on histopathological and immunohistochemical studies, the latter showing positivity to $\mathrm{CD} 20, \mathrm{BCl}-2$, and $\mathrm{BCl}-6$. After treatment with radiotherapy the patient has shown a 4.4-year follow-up free of disease.
\end{abstract}

\section{Introduction}

In the early 1990s, the term primary cutaneous B-cell lymphoma (PCBCL) was introduced to indicate a heterogeneous group of lymphoproliferative disorders primarily involving the skin [1]. Nowadays, the new WHO-EORTC (World Health OrganizationEuropean Organization for Research and Treatment of Cancer) classification for 


\begin{tabular}{l|l|l|l} 
Case Reports $h$ & Case Rep Dermatol 2009;1:87-92 & Published online: November 11, 2009 & $\begin{array}{l}\text { ○ 2009 S. Karger AG, Basel } \\
\text { ISSN 1662-6567 } \\
\text { www.karger.com/cde }\end{array}$ \\
\hline
\end{tabular}

cutaneous lymphomas identifies four main types of PCBCLs: (1) primary cutaneous marginal zone B-cell lymphoma (PCMZL); (2) primary cutaneous follicle center lymphoma (PCFCL); (3) primary cutaneous large B-cell lymphoma leg-type (PCLBCLLT); and (4) primary cutaneous large B-cell lymphoma, other (PCLBCL-other) [2]. The description of PCLBCL-LT as a subset of PCBCL was first reported in 1996 [1]; since then many cases have been recognized [3-5].

PCLBCL-LT is diagnosed by the presence of confluent sheets of medium-sized to large $B$ lymphocytes with round nuclei provided with evident nucleoli, resembling centroblasts or immunoblasts, which express Bcl-6, Bcl-2. In this update of the classification, the localization on the leg is incidental to the immunohistological aspects, which represent the diagnostic criteria, irrespective of the site of onset. This explains the new term 'legtype' instead of the previous 'of the leg'. Locations other than the legs have been reported to be sporadic even in large series of patients [4]; in particular, trunk localization is found in 7.5-13.3\% of all PCLBCL-LT [4-7]. Prognosis of PCLBCL-LT has an intermediate level severity and depends on pathological features, presence of multiple skin lesions (but not the spread of a single one), age of the affected patients and disease duration before diagnosis $[2,4-6,8]$.

We describe a patient with a peculiar clinical presentation and an early age of onset with a single light red lesion, $4 \mathrm{~cm}$ in diameter, on the dorsum diagnosed as typical PCLBCL-LT on immunohistological grounds.

\section{Case Report}

In November 2004, a 52-year-old man was referred to us for a skin lesion that he had noticed 2 years before and which had been stable and asymptomatic until a sudden and rapid growth during the last 2 months (fig. 1). Family and personal history was negative for skin diseases and the patient had always been in good health.

Physical examination revealed a light red infiltrated round plaque located on the dorsum, medially to the scapulae, with a diameter of $4 \mathrm{~cm}$, without signs of surrounding edema. This lesion was very firm, with a very compact consistency and a hard texture to the touch, such as to present a temporary difficulty in executing the external incision through a commonly used scalpel. Moreover, once the biopsy was performed, there remained a well demarcated lozenge cavity and the skin flaps were very hard to draw together.

The remaining dermatological examination was negative and superficial lymph nodes were not enlarged.

The biopsy was fixed in formalin and embedded in paraffin. Three-micron-thick sections were stained for hematoxylin-eosin (fig. 2), Giemsa and cut for immunohistochemistry, the latter being performed by applying previously reported antigen unmasking procedures [9] and the AAAP technique [10]. Histology showed a dense diffuse lymphoid infiltrate located in the papillary and reticular dermis, composed of sheets of large pleomorphic cells with multiple nucleoli and variably basophilic cytoplasm, resembling centroblasts and immunoblasts. No epidermotropism was evident. Immunohistochemistry demonstrated positivity for CD20, Bcl-2 (ig. 3 ) and Bcl-6, and negativity for CD10, with high proliferation index. MUM1/IRF4 test was performed on the bioptic paraffined specimen on May 2008 and was negative.

The staging procedures excluded an extra-cutaneous involvement of the disease. On the basis of the clinical and immunohistological features a diagnosis of PCLBCL-LT was made. The patient underwent localized radiotherapy with good response and after a 4.4-year disease-free follow-up, no signs of relapse are present. 


\section{Discussion}

PCLBCL-LT usually affects elderly patients during the 7th decade of life and presents a female predominance $[4,5,7,11]$. This subset encompasses approximately $1-3 \%$ of all cutaneous lymphomas and 5-10\% of PCBCL [12]. PCLBCL-LT is classified as a cutaneous B-cell lymphoma with an intermediate clinical behavior and a 5-year survival of $41 \%$ [2]. The typical clinical presentation of PCLBCL-LT is a unique red or violaceous rapidly growing nodule, frequently ulcerated and located on the lower limbs. We believe our case to be interesting for its atypical clinical presentation and outcome. In fact, the lesion was located on the dorsum, which has only been sporadically reported [5] as an onset site, and presented as a firm light red plaque without ulceration; the latter aspect may be explained by the recent growth of the lesion, which had previously been stable for 2 years. Moreover, the age of the patient (52 years) is significantly lower than the mean age reported in the literature for PCLBCL-LT [2-5].

Despite this unusual clinical presentation, the case fits well into this category on histological and immunohistochemical grounds, by showing sheets of pleomorphic large $\mathrm{B}$ cells growing diffusely, with positivity for Bcl-6, Bcl-2, and CD20 as well as CD10 and IRF4 negativity, as reported $[2,13]$.

Regarding the clinical course, PCLBCL-LT is reported to behave more aggressively than the other PCBCLs with large cell component [1]. This is partly due to the Bcl-2 expression. In reality, cases of PCLBCLs occurring outside the legs, but with the same morphologic and immunophenotypic pattern, can also be indicated as PCLBCL of the leg type', meaning that they present similarly to the variant classically occurring in the leg. The adverse prognostic impact of the Bcl-2 expression has recently been substantiated by gene expression profiling studies showing high expression levels of apoptosis-inducing cytotoxic effector genes, which lead to the constitutive inhibition of apoptotic pathways in the neoplastic cells $[14,15]$.

To our knowledge, in all the reports written in English [4-7] involving large series of patients since the new WHO-EORTC classification for PCLBCLs, only 25 patients with a solitary trunk/dorsum involvement have until now been mentioned out of 209 patients with a diagnosis of PCLBCL-LT, thus confirming the extreme rarity of our patient's case: the localization of the lesion, the behavior of the lesion before and after diagnosis (before: single, non ulcerated, slow growing lesion, not spreading; after: good response to radiotherapy with a 4.4-year follow-up free of disease), the age of the patient at disease onset (52 vs. more than 70 years), the fact that despite some unfavorable prognostic parameters (Bcl-2+; 2-year old lesion, pathological features) the disease-free follow-up is long. Our case might underline the lack of reports on this rare subclass of patients with non-leg PCLBCL-LT, while in future analyses of such patients the parameters and clinical behavior of non-leg PCLBCL-LT should be extrapolated and pondered. 


\begin{tabular}{|c|c|c|c|}
\hline $\begin{array}{l}\text { Case Reports in } \\
\text { Dermt io acy }\end{array}$ & $\begin{array}{l}\text { Case Rep Dermatol 2009;1:87-92 } \\
\text { D0I: } \underline{10.1159 / 000253874}\end{array}$ & Published online: November 11, 2009 & $\begin{array}{l}\text { @ } 2009 \text { S. Karger AG, Basel } \\
\text { ISSN 1662-6567 } \\
\text { www.karger.com/cde }\end{array}$ \\
\hline
\end{tabular}

Fig. 1. Plaque on the dorsum, light red, firm and infiltrated.

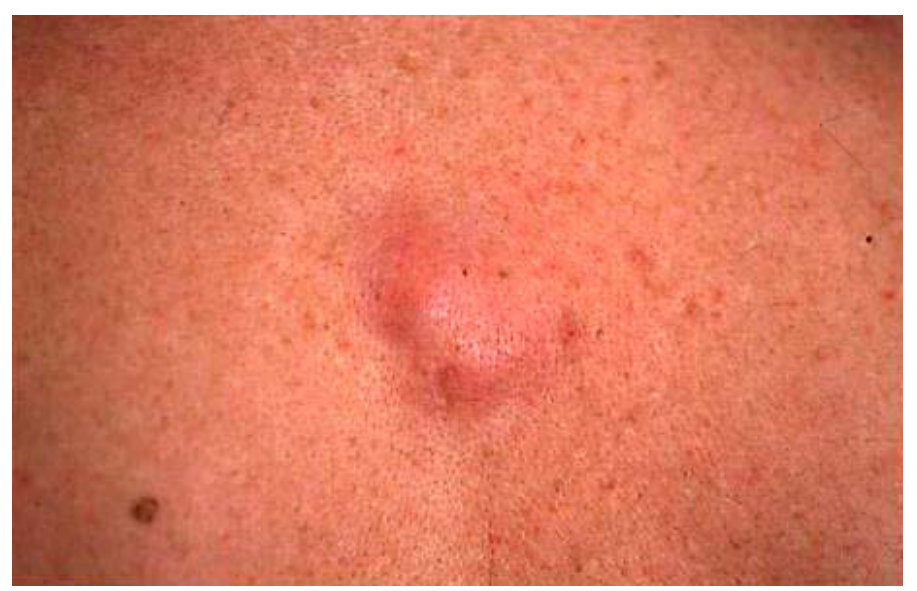

Fig. 2. Diffuse lymphocytic infiltrate in the papillary and reticular dermis. HE. Original magnification $\times 40$.

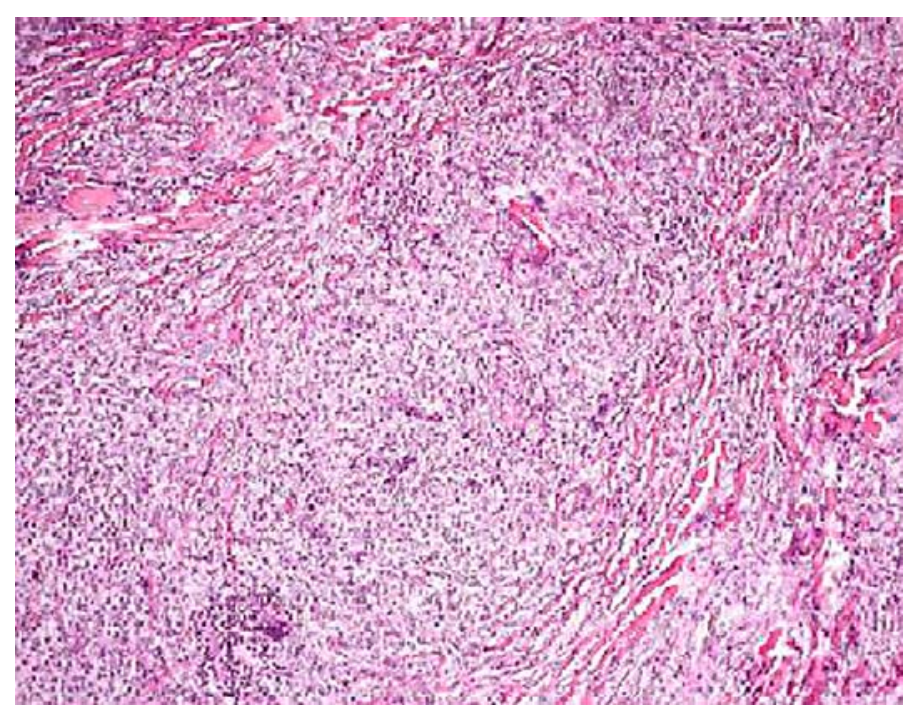




\begin{tabular}{c|l|l|l}
$\begin{array}{c}\text { Case Reports } h \\
\text { Denmitolagy }\end{array}$ & $\begin{array}{l}\text { Case Rep Dermatol 2009;1:87-92 } \\
\text { D0I: 10.1159/000253874 }\end{array}$ & Published online: November 11, 2009 & $\begin{array}{l}\text { O 2009 S. Karger AG, Basel } \\
\text { ISSN 1662-6567 } \\
\text { www.karger.com/cde }\end{array}$ \\
\hline
\end{tabular}

Fig. 3. Tumor cells contain cytoplasmic Bcl-2 staining. Bcl-2 immunoperoxidase. Original magnification $\times 64$.

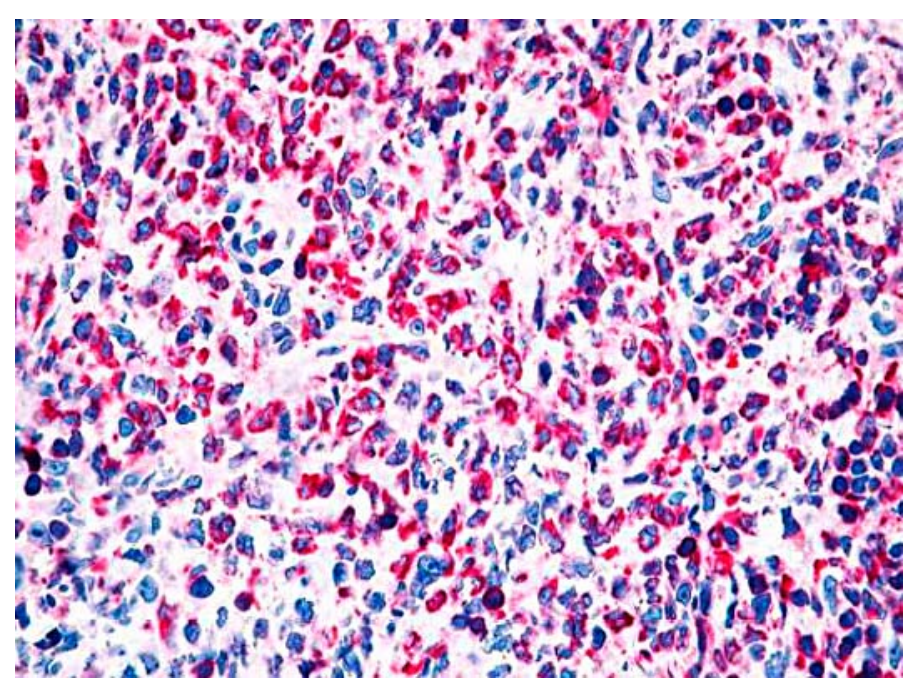




\section{References}

-1 Vermeer MH, Geelen FA, van Haselen CW, van Voorst Vader PC, Geersts ML, van Vloten WA, Willemze R: Primary cutaneous large B-cell lymphomas of the legs. A distinct type of cutaneous B-cell lymphoma with an intermediate prognosis. Dutch Cutaneous Lymphoma Working Group. Arch Dermatol 1996;132:1304-1308.

-2 Willemze R, Jaffe ES, Burg G, Cerroni L, Berti E, Swerdlow SH, Ralfkiaer E, Chimenti S, Diaz-Perez JL, Duncan LM, Grange F, Harris NL, Kempf W, Kerl H, Kurrer M, Knobler R, Pimpinelli N, Sander C, Santucci M, Sterry W, Vermeer $\mathrm{MH}$, Wechsler J, Whittaker S, Meijer CJ: WHO-EORTC classification for cutaneous lymphomas. Blood 2005;105:3768-3785.

3 Brogan BL, Zic JA, Kinney MC, Hu JY, Hamilton KS, Greer JP: Large B-cell lymphoma of the leg: clinical and pathologic characteristics in a North American series. J Am Acad Dermatol 2003;49:223-228.

-4 Grange F, Beylot-Barry M, Courville P, Maubec E, et al: Primary cutaneous diffuse large B-cell lymphoma, leg type: clinicopathologic features and prognostic analysis in 60 cases. Arch Dermatol 2007;143:1144-1150.

-5 Senff NJ, Hoefnagel JJ, Jansen PM, Vermeer MH, van Baalen J, Blokx WA, Canninga-van Dijk MR, Geerts ML, Hebeda KM, Kluin PM, Lam KH, Willemze R: Reclassification of 300 primary cutaneous $B$ cell lymphomas according to the new WHO-EORTC classification for cutaneous lymphomas: comparison with previous classifications and identification of prognostic markers. J Clin Oncol 2007;25:1581-1587.

-6 Zinzani PL, Quaglino P, Pimpinelli N, Berti E, Baliva G, Rupoli S, Martelli M, Alaibac M, Borroni G, Chimenti S, Alterini R, Alinari L, Fierro MT, Cappello N, Pileri A, Soligo D, Paulli M, Pileri S, Santucci M, Bernengo MG; Italian Study Group for Cutaneous Lymphomas: Prognostic factors in primary cutaneous Bcell lymphoma: the Italian Study Group for Cutaneous Lymphomas. J Clin Oncol 2006;24:1376-1382.

-7 Kodama K, Massone C, Chott A, Metze D, Kerl H, Cerroni L: Primary cutaneous large B-cell lymphomas: clinicopathologic features, classification, and prognostic factors in a large series of patients. Blood 2005;106:2491-2497.

8 Hallermann C, Niermann C, Fischer RJ, Schulze HJ: New prognostic relevant factors in primary cutaneous diffuse large B-cell lymphomas. J Am Acad Dermatol 2007;56:588-597.

-9 Pileri S, Ascani S, Milani M, Visani G, Piccioli M, Arcioni GF, Poggi S, Sabattini E, Santini D, Falini B: Acute leukaemia immunophenotyping in bone-marrow routine sections. Br J Haematol 1999;105:394-401.

-10 Cordell JL, Falini B, Erber WN, Ghosh AK, Abdulaziz Z, MacDonald S, Pulford $\mathrm{KA}$, Stein H, Mason DY: Immunoenzymatic labeling of monoclonal antibodies using immune complexes of alkaline phosphatase and monoclonal anti-alkaline phosphatase (APAAP complexes). J Histochem Cytochem 1984;32:219-229.

-11 Grange F, Bekkenk MW, Wechsler J, Meijer CJ, Cerroni L, Bernengo M, Bosq J, Hedelin G, Fink Puches R, van Vloten WA, Joly P, Bagot M, Willemze R: Prognostic factors in primary cutaneous large B-cell lymphoma: a European multicenter study. J Clin Oncol 2001;19:3602-3610.

-12 Pandolfino TL, Siegel RS, Kuzel TM, Rosen ST, Gultart J: Primary cutaneous Bcell lymphoma: review and current concepts. J Clin Oncol 2000;18:2152-2168.

13 Paulli M, Viglio A, Vivenza D, Capello D, et al: Primary cutaneous large B-cell lymphoma of the leg: histogenetic analysis of a controversial clinicopathologic entity. Human Pathology 2002;33:937-943.

14 Hoefnagel JJ, Dijkman R, Basso K, Jansen PM, Hallermann C, Willemze R, Tensen CP, Vermeer MH: Distinct types of primary cutaneous large B-cell lymphoma identified by gene expression profiling. Blood 2005;105:3671-3678.

15 Van Galen JC, Hoefnagel JJ, Vermeer MH, Willemze R, Dijkman R, Tensen CP, de Boer WP, Meijer CJ, Oudejans JJ: Profiling of apoptosis genes identifies distinct types of primary cutaneous large B cell lymphoma. J Pathol 2008;215:340-346. 